\title{
Mora'akeke Ceremony as a Local Indigenous Material in Indonesian for Speakers of Other Language Class: an Autoethnography studies in Palu, Central Sulawesi
}

\author{
Asrianti $^{1}$, Eko Widianto $^{2}$ \\ \{asriantid3@gmail.com¹, eko.widianto@umk.ac.id² \\ ${ }^{1}$ Universitas Tadulako, Indonesia \\ ${ }^{2}$ Universitas Muria Kudus, Indonesia
}

\begin{abstract}
Mora'akeke was one of the famous a local indigenous ceremony in Palu, Central Sulawesi. Thus, a popularity of this indogenous should be introducted to the foreigner who came to Palu, as well as Universitas Tadulako. This study aimed to describe 1) Mora'akeke ceremony as a local indigenous in as a learning material in BIPA; 2) the cultural function of Mora'akeke ceremony for BIPA learners in Palu, Central Sulawesi; 3) Mora'akeke ceremony as a cultural diplomatic way through BIPA. In this study, the authors used authoethnography method. Furthermore, the experience in BIPA class will be described as a research data.
\end{abstract}

Keywords: mora'akeke ceremony, local indigenous, bipa

\section{Introduction}

BIPA or Indonesian for foreign speakers has several dimensions (Suhardijanto ${ }^{[1]} 2016$; Wurianto $^{[2]}$ 2016; and Damaianti ${ }^{[3]}$ 2016). These dimensions are BIPA as a science, as an industry, as a profession, and as a means of diplomacy. For this reason, the mandate of BIPA is not just in the classroom as teaching Indonesian for foreign citizens. However, BIPA has become a complex space that includes a vision of introducing Indonesian culture on the international cooperation.

Various cultures have colored the teaching of BIPA over time. Local culture is also an integral part of BIPA teaching, both domestically and abroad (Widianto ${ }^{[4]} 2016 \& 2017^{[5]}$; and Siroj $^{[6]}$ 2012). Local culture not only provides students with archaeological insights, it is also a bridge to cultural understanding or is often called cross-cultural understanding. Thus, the BIPA class provides a supply for its students to avoid cultural shock.

The introduction of culture in language learning can be done by preparing local-based teaching materials. The culture that BIPA students will teach is a local tradition or tradition that they will learn during language learning. One of the cultural introductions that will be included in the teaching as a development of local culture-based teaching materials is the Mora'ekeke Ceremony. The ceremony is a tradition practiced by the people of Central Sulawesi to avoid natural disasters. 


\section{Method}

This research was designed using the autoetnographic method. A study by directly involved in the process and the discovery of its results. For this reason, in this study, researchers also act directly as practitioners. In addition, the data is presented with a qualitative descriptive method with interpretation of non-formal data.

\section{Discussion}

\section{1) Mora'akeke ceremony as a local indigenous in as a learning material in BIPA}

The ceremony for rain in the Palu region of Central Sulawesi in the Kaili tribe is known by the term Mora'ekeke which is etymologically formed from the word Mora 'and Keke. Mora 'is a traditional form of ritual performed through the symbol of sacrificial acts, that is, sacrificing / slaughtering animals to obtain blood as a ransom for the sins of the individual parties. Next, Keke is in the Kaili dialect which means river. Keke is the center of ceremonial maintenance, because the river is considered sacred, easy to associate with water gods and is considered the right place to drain the blood of sacrificed animals. Mora'ekeke is a traditional form of rejection of the occult because of drought by sacrificing certain animals upstream in an effort to establish a magical world connection to keep the drought away.

After the community felt a prolonged drought and noticed that the water flowing from the headwaters of the river was getting less, then through traditional parents it was proposed to the king about the necessity of holding a ceremony for rain. The King was asked for blessing and the considerations regarding the ceremony period were emphasized at the meeting.

The ceremonial place is a place that is considered sacred to have magical resources, because of the existence of a power that is in that place, and asks for the occurrence of natural events according to his wishes. It is described as a guardian and occupant of a certain place called the God of water.

According to the community budget, if the water that flows from the headwaters of the river is increasingly decreasing, it indicates the wrath of the water god, so in that place it is necessary to hold a ceremony by offering certain animals based on customary guidance. Reduced water in the headwaters of the river, closely related to rainfall. Both are determined by one natural force controlled by one god, the god of water. The water god named Inteka who inhabits river water.

There are several unique or mythological locations in the ceremony. These mythologies are,

1) the Kaili people hold deliberations to reach consensus without discriminating social status;

2) Kaili people are used to working together in doing a job; 3) the Kaili people highly respect their ancestors; and 4) the Kaili tribe believes that all the calamities that have taken place are a form of reprimand for the sins committed.

This particular Moraakeke culture can be used as teaching material in teaching BIPA. This is in line with text-based teaching in BIPA. Moraakeke is located as a complex text and gives a complete description of life in Palu. Students can learn the values that develop in Palu as the main provision in socializing and socializing. As such, they don't just learn languages. However, they are also able to recognize, appreciate, and practice the local culture that is trusted by the local community. 


\section{2) The cultural function of Mora'akeke ceremony for BIPA learners in Palu, Central Sulawesi}

The Moraakeke ceremony in Palu has several functions. First, this ceremony serves to maintain the sustainability of rainfall, so that the only source of livelihood of the population is given fertility and blessing, so as to provide multiple and satisfying results. In addition, the community also believes that this ceremony was carried out so that the water god named Intenka could give his blessing through religious magical nature. In addition, this ceremony is used as an effort to cleanse humans from all sins that cause the misery of society by causing prolonged drought.

The Moraakeke tradition needs to be introduced to BIPA students, especially in the Palu area. It aims to provide local insights for learners. In addition, this tradition has a sacred value. Therefore, values that are trusted by the local community need to be known by BIPA students. Thus, students can be wise and be able to respect the local specialties in their homes.

\section{3) Mora'akeke ceremony as a cultural diplomatic way through BIPA.}

The introduction of culture in BIPA still relies on the culture of the archipelago that is commonly known. The culture explored by teachers has not yet penetrated into the local peculiarities that exist near learners. This is due to the lack of local cultural literature. For this reason, local culture needs to be explored as teaching materials and learning media in the BIPA class. Thus, local cultural diplomacy can also be one of the BIPA teaching missions both at home and abroad.

The introduction of Moraakeke culture brings BIPA students closer to Palu with the local socio-cultural situation. Moraakeke as a mythological tradition is an attraction for BIPA students. In addition, this culture can also instill the noble values that exist in Palu to BIPA students. The effect of this learning can provide wisdom in the learner. In addition, students also get closer to the socio-cultural conditions in Palu, Central Sulawesi.

This introduction result to Moraakeke culture can also strengthen Indonesia's identity as a multicultural country. Other nations will recognize Indonesia with its cultural diversity. Culture that is known not only cultures that are already popular, but local cultures that exist and develop in the midst of local communities. Thus, cultural diplomacy occurs well in the teaching of BIPA.

\section{Conclussion}

Local culture or Moraakeke ceremony is considered appropriate as teaching material in BIPA. This culture can be used as a means of local cultural diplomacy. The process of local cultural diplomacy is not only able to raise local uniqueness on the international scene. However, it is also able to instill local values in the lives of BIPA students while living with the local community. Thus, they can live wisely and respect each other with Indonesian citizens.

\section{References}

[1] Suhardijanto, Totok. 2016. "Tantangan dan Peluang Pengembangan BIPA di Masa Mendatang: Penguatan Dimensi-Dimensi BIPA". Prosiding SEMAR BIPA 2016. Universitas Negeri Semarang. Volume I. Hal. 10-17.

[2] Wurianto, Arif Budi. 2016. "Pengembangan dan Pembelajaran BIPA Berbasis Lintas Budaya". Prosiding SEMAR BIPA 2016. Universitas Negeri Semarang. Volume I. Hal. 18-25. 
[3] Damaianti, Vismaia S. 2016. "Internalisasi Wawasan Kebangsaan dalam Menguatkan Citra Diri Bangsa Para Pengajar BIPA". Prosiding SEMAR BIPA 2016. Universitas Negeri Semarang. Volume I. Hal. 26-29.

[4] Widianto, Eko. 2016. "Budaya Lokal Joglosemar dalam Pembelajaran Membaca-Menulis Bagi Pembelajar BIPA Tingkat Dasar”. Prosiding SEMAR (Seminar Kepakaran) BIPA: Volume 1. APPBIPA Jawa Tengah. Hal 102-108.

[5] Widianto, Eko. 2017. "Media Wayang Mini dalam Pembelajaran Keterampilan Berbicara Bagi Pemelajar Bipa A1 Universitas Ezzitouna Tunisia" Kredo: Jurnal Ilmiah Bahasa dan Sastra. Volume 1 Nomor 1. Universitas Muria Kudus. Halaman 120-143.

[6] Siroj, Badrus. 2012. Pengembangan Model Integratif Bahan Ajar Bahasa Indonesia Ranah Sosial Budaya Berbasis ICT bagi Penutur Asing Tingkat Menengah. (Tesis). Jurusan Sastra Indonesia Universitas Negeri Semarang. 